\title{
Agro-industrial byproducts as modification enhancers of the bacterial cellulose biofilm surface properties: An inverse chromatography approach
}

\author{
Marisa Faria $^{\mathrm{a}, \mathrm{b}}$, Fatemeh Mohammadkazemi ${ }^{\mathrm{c}}$, Roberto Aguiar ${ }^{\mathrm{a}}$, Nereida Cordeiro ${ }^{\mathrm{a}, \mathrm{b}, *, 1}$ \\ ${ }^{a}$ LB3, Faculty of Exact Science and Engineering, University of Madeira, 9020-105 Funchal, Portugal \\ ${ }^{\mathrm{b}}$ CIIMAR - Interdisciplinary Centre of Marine and Environmental Research, University of Porto, 4450-208 Porto, Portugal \\ ${ }^{\mathrm{c}}$ Department of Biosystems, Faculty of New Technologies Engineering, Shahid Beheshti University, Evin, P.O. Box 19839-4716, Tehran, Iran
}

\section{A R T I C L E I N F O}

\section{Keywords:}

Bacterial cellulose

Surface characterization

Low-cost carbon sources

Cellulose biosynthesis

Date syrup

IGC

\begin{abstract}
A B S T R A C T
Bacterial cellulose (BC) has remarkable and excellent properties. However, the high-cost production and the use of chemicals for BC modification make its application unattractive. A simple approach to modify the properties of BC during biosynthesis, by using alternative low-cost carbon sources from agro-industrial byproducts, was studied. The carbon source (date syrup, mannitol, sucrose, food-grade sucrose, and glucose) significantly changed the BC network morphology and structure. Date syrup source induces the highest modifications in the surface properties of BC: smaller area $\left(S_{B E T}=4.04 \mathrm{~m}^{2} / \mathrm{g}\right)$, higher hydrophobic $\left(\gamma_{s}^{d}=45.79 \mathrm{~mJ} / \mathrm{m}^{2}\right)$ and basic character $\left(K_{b} / K_{a}=1.10\right)$, at $25^{\circ} \mathrm{C}$. Food-grade sucrose source resulted in the lowest yield of BC production (37\% less), however caused an increase in the BC network reticulation and a high crystalline structure (IC $=82.3 \%$ ). This sustainable and simple methodology presents a low-cost and efficient approach allowing the modulation of the surface properties of BC.
\end{abstract}

\section{Introduction}

New biomaterials derived from natural resources have been the focus of many researchers due to their attractive properties and nature, contributing to a sustainable technology. Bacterial cellulose (BC) is a natural biotechnological product biosynthesized at the liquid/air interface mainly from the Gluconacetobacter sp. genus bacteria, currently known as Komagataeibacter sp. Its promising characteristics - a unique and sophisticated 3D nanoporous network with high crystallinity, a high degree of polymerization, high water content capacity, high permeability to liquid and gas, high purity, good biocompatibility, non-toxicity and biodegradability - make it an excellent natural biomaterial (Moosavi-Nasab and Yousefi, 2011; Hussain et al., 2019). With outstanding surface and morphologic properties, BC could be tailored for pharmaceutical, immobilization platforms, filtration, electronic, cosmetics, food, energy production and other applications, via in situ or/and ex situ modifications or in the microorganism co-culture (Blanco Parte et al., 2020). Different surface properties such as wettability, acid and base character, porosity, gas permeability and roughness play a crucial role in the performance of $\mathrm{BC}$ nanocomposites for a given application. In the pharmaceutical field, BC were modified to change porosity and water-holding capacity for wound dressing, antimicrobial activity, drug delivery, tissue regeneration and vascular grafts (Blanco Parte et al., 2020; Stumpf et al., 2013; Rühs et al., 2018; Gonçalves et al., 2016; Brackmann et al., 2012; Bodin et al., 2010; Pötzinger et al., 2017). For biotechnological approaches, Rühs et al. (2018) report an efficient approach to form a macroporous BC foam by foaming a mannitol-based media with a bacterial suspension, increasing the surface area of the BC. By adding different paraffin particles of various sizes to the culture medium, Bodin et al. (2010) obtained porous BC scaffolds suitable to use in tissue-engineered urinary conduits for urinary reconstruction. Gonçalves et al. (2016) reduced the hydrophilicity of BC through acetylation and polysaccharide adsorption, using chitosan and carboxymethyl cellulose to improve cell adhesion and proliferation. BC can also be used as a sustainable filter material as reported by Fang et al. (2016). High-performance separation membrane based on BC and graphene oxide through vacuum was developed, where the graphene oxide nanosheets were spread on porous BC skeleton. In cosmetics, silk sericin $\mathrm{BC}$ facial masks were used for facial treatment, as well as caffeine release from BC for cellulite treatment (Blanco Parte et al., 2020; Silva et al.,

\footnotetext{
* Corresponding author at: LB3, Faculty of Exact Science and Engineering, University of Madeira, 9020-105 Funchal, Portugal.

E-mail address: ncordeiro@staff.uma.pt (N. Cordeiro).

1 ORCID ID: 0000-0001-6006-3415
} 
2014). For aerogel formation, BC aerogel could be obtained by using a supercritical carbon dioxide anti-solvent precipitation method and/or by incorporating different compatible polymers to form composite BC aerogels (Pircher et al., 2014). In textile applications, wettability is an important characteristic of BC-based materials when superhydrophobic BC-based materials are required to develop leather-like materials, as reported by Krishnamurthy et al. (2020).

Industrially, the high costs of production and chemical-based modifications are considered the real obstacles to producing $\mathrm{BC}$ and the synthesis of nanocomposites (Jozala et al., 2016). Thus, the implementation of a low-cost, simple, and sustainable approach to modify BC using new carbon sources in the biosynthesis are crucial for the economic viability of BC in broader biotechnological domains. Following these research lines, in the present research, a new approach to modify the properties of $\mathrm{BC}$ will be explored: the use of different carbon sources.

Carbohydrates are an essential carbon source that plays a key role in BC biosynthesis. Glucose is the most widely available simple carbohydrate and the most common carbon source used in the production of BC. In recent years, the use of industrial and agricultural by-products as alternative sources of nutrients for $\mathrm{BC}$ production has been the target of an alternative approach to achieving more environmentally friendly $\mathrm{BC}$ production and reducing production costs (Urbina et al., 2017; Tsouko et al., 2015). In the current work, two low-cost alternative food-grade carbon sources were used for BC biosynthesis: date syrup and food-grade sucrose. Date fruit, from Phoenix dactylifera L., is produced largely in the hot arid regions of Southwest Asia and North Africa. As a by-product of the date fruit industry, date syrup is a viscous solution rich in carbohydrates (about $75 \mathrm{wt} \%$ ) (Al-Hooti et al., 2002). Depending on the date fruit stage: (i) hababouk, (ii) khimri, (iii) khalal, (iv) rutab and (v) tamar, the sugar date syrup content varies between non-reducing sugar (sucrose - stage (iii)) and reducing sugars (glucose and fructose - stages (iv) and (v)) (Ashraf and Hamidi-Esfahani, 2011). Food-grade sucrose is obtained industrially mostly from sugarcane (Saccharum officinarum) and sugar beet (Beta vulgaris ssp. vulgaris var. altissima). Depending on the sugar source and the extent of sugar refinement, the chemical composition differs: a refined sugar consists of practically $100 \%$ sucrose; a washed raw beet sugar is approximately $96 \%$ sucrose, $<1.4 \%$ moisture, $0.9 \%$ ash and $1.5 \%$ non-sugar organic compounds, and berry sugar contains $98.8 \%$ sucrose, $0.70 \%$ moisture, $0.20 \%$ ash and $0.29 \%$ non-sugar organic substances (Belitz and Grosch, 1999). Food-grade sucrose differs from sucrose in its purity due to its refinement and processing.

Published studies using alternative carbon sources for BC biosynthesis are focused on the yield, crystallinity, and morphology effect on the obtained BC (Mohite and Patil, 2014; Park et al., 2010; Forestia et al., 2017). The effect of alternative carbon sources on the surface properties of $\mathrm{BC}$ has not been studied until now, despite the importance of the surface proprieties to the applications of $\mathrm{BC}$. Thus, the main goal of this study was to evaluate different carbon sources as enhancers of the surface properties of $\mathrm{BC}$ during biosynthesis, including low-cost alternative carbon sources. Inverse Gas Chromatography (IGC) was employed as a powerful analytical tool to understand how carbon sources can influence the surface properties of BC. Parameters such as the dispersive component of surface energy $\left(\gamma_{s}^{d}\right)$ and the specific Gibbs free energy of adsorption $\left(\Delta G_{a d s}^{s p}\right)$, as well as the surface area $\left(S_{B E T}\right)$, maximum adsorption potential $\left(A_{\max }\right.$. $)$ and acid and base surface character $\left(K_{b}\right.$ and $\left.K_{a}\right)$, were determined. Nevertheless, other analytical techniques, namely Scanning Electronic Microscopy (SEM), Attenuated total reflectance - Fourier transformed infrared spectrometer (ATR-FTIR), X-ray spectroscopy (EDX) and X-ray diffraction (XRD) were used to support the results found via the IGC analysis.

\section{Materials and methods}

\subsection{Materials}

The bacterial strain used in the present work was Gluconacetobacter xylinus, obtained from the Persian Type Culture Collection (PTCC 1734), Iran. $n$-alkanes and the polar probes used for the IGC measurements were all GC grade (> 99\%) supplied by Sigma-Aldrich. The methane gas (reference probe) and helium (carrier gas) of high purity (>99.99\%) were supplied by Air Liquide Company. Hestrin-Schramm (HS) medium materials were purchased from Merck company, Germany. Glucose, mannitol, and sucrose were supplied by Sigma-Aldrich ( $>99.5 \%$ ). Date syrup and food-grade sucrose were industrial food products purchased from Khuzestan and Karaj Sugar Factory, Iran, respectively.

\subsection{Bacterial cellulose production}

G. xylinus has growth in HS medium using five carbon sources: glucose, date syrup, mannitol, sucrose, and food-grade sucrose (Table S1). The HS media, after being autoclaved at $121^{\circ} \mathrm{C}$ for $15 \mathrm{~min}$, were inoculated with a bacterial concentration of $10 \%(\mathrm{v} / \mathrm{v})$. Ethanol $1 \%(\mathrm{v} / \mathrm{v})$ was added to all used media and the $\mathrm{pH}$ was adjusted to 5.5 with $\mathrm{H}_{2} \mathrm{SO}_{4}$. Then, the cultures were incubated at $28{ }^{\circ} \mathrm{C}$ and stirred at $150 \mathrm{rpm}$ for seven days. The resulting BC membranes were washed with $1 \mathrm{wt} \% \mathrm{NaOH}$ solution at $80^{\circ} \mathrm{C}$ for $1 \mathrm{~h}$, washed with distilled water until reaching the neutral $\mathrm{pH}$, and then dried overnight at $40{ }^{\circ} \mathrm{C}$.

\subsection{Inverse gas chromatograph (IGC)}

IGC measurements were carried out on a commercial inverse gas chromatograph (iGC, Surface Measurements Systems, London, UK) equipped with flame ionization (FID) and thermal conductivity (TCD) detectors. The IGC system is fully automatic with SMS iGC Controller v1.8 control software. Data was analyzed using iGC Standard v1.3 and Advanced Analysis Software v1.25. IGC theory is described in detail in Cordeiro et al. (2011). The samples were packed, using vertical tapping for $2 \mathrm{~h}$, in standard glass silanized (dymethyldichlorosilane; Repelcote $\mathrm{BDH}, \mathrm{UK}$ ) columns with $0.2 \mathrm{~cm}$ internal diameter and $30 \mathrm{~cm}$ length. Before measurements, the columns with the samples were conditioned for $8 \mathrm{~h}$ at $40^{\circ} \mathrm{C}$ (to remove adsorbed water) and $2 \mathrm{~h}$ at the measurement conditions (to stabilize the conditions in the columns). After conditioning, pulse injections were carried out with a $0.25 \mathrm{ml}$ gas loop. Four $n$-alkanes (heptane, octane, nonane and decane) were used to measure the dispersive component of surface free energy $\left(\gamma_{s}^{d}\right)$ at $25^{\circ} \mathrm{C}$. To study the $\gamma_{s}^{d}$ variation with the temperature $\left(d \gamma_{s}^{d} / d T\right.$ ), the $\gamma_{s}^{d}$ was determined also at 20 and $30{ }^{\circ} \mathrm{C}$. Four polar probes (tetrahydrofuran-THF, ethanol-EtOH, ethyl acetate- EtAc and acetonitrile-ACN) were used to measure specific Gibbs free energy of adsorption $\left(\Delta G_{a d s}^{s p}\right)$, and the acid and base surface character $\left(K_{b}\right.$ and $K_{a}$ ), at $25{ }^{\circ} \mathrm{C}$ (Cordeiro et al., 2011; Cava et al., 2007; Voelkel, 2006). Due to the very low retention times to chloroalkanes, these probes were not used in the $\Delta G_{a d s}^{s p}, K_{b}$ and $K_{a}$ calculations. The isotherm experiment (used to know the sample energetic profile and to determine the BET surface area $\left(S_{B E T}\right)$ and the maximum adsorption potential $\left(A_{\max }\right)$ ) was undertaken with $n$-octane at 0.05 , $0.07,0.09,0.1,0.2,0.4,0.6,0.8$ and $0.95 \mathrm{p} / \mathrm{p}^{0}$ for the samples tested at $25{ }^{\circ} \mathrm{C}$. The retention volume was used to determine the adsorption isotherm by the BET equation (Thielmann, 2004), and knowing the monolayer capacity and the cross-section area of the probe molecule, the $S_{B E T}$ was be calculated (Cordeiro et al., 2011; Witkiewicz and Slomkiewicz, 2019).

All experiments were carried out at $0 \%$ of relative humidity with a helium flow rate of $10 \mathrm{ml} / \mathrm{min}$ and in duplicate, producing errors of less than $4 \%$. 


\subsection{Field emission scanning electron microscopy (FE-SEM) and X-ray spectroscopy (EDX)}

For field emission scanning electron microscopy (FE-SEM) imaging, the samples were gold-coated using the field-emission SEM Hitachi SU 8090. The identification of the chemical compositions of the samples and the semi-quantitative analysis were carried out by energy-dispersive X-ray spectroscopy (EDX). Quantitative analyses were done for weight percentages (wt\%) of the elements. Both the FE-SEM and EDX experiments were conducted at an accelerated voltage of $5 \mathrm{kV}$. Before measurements, all samples were dried at $40{ }^{\circ} \mathrm{C}$ for $72 \mathrm{~h}$ and kept in a desiccator until analysis.

\subsection{Attenuated total reflectance - Fourier transformed infrared spectrometer (ATR-FTIR)}

Infrared spectroscopy of the samples was performed on a Bruker Equinox 55 analyzer, equipped with a DTGS detector and a golden gate micro-ATR. The spectra were collected at wavenumbers ranging between 4000 and $600 \mathrm{~cm}^{-1}$, with an average of 16 scans. All samples were dried in a vacuum oven at $40{ }^{\circ} \mathrm{C}$ for $72 \mathrm{~h}$ and kept in a desiccator until analysis.

\subsection{Cluster analysis}

Multivariate statistical analysis was performed using MINITAB 17 Statistical Software. This method allows visualization of a multivariate data set and detects the relationship between variables and objects in a reduced data dimension. Hierarchical agglomerative clustering was used to achieve the similarity between IGC data through the linkage distance (Square Euclidean distance), using the Ward linkage. The dispersive component of surface free energy $\left(\gamma_{s}^{d}\right)$ and its temperature dependence $\left(\Delta \gamma_{s}^{d} / \Delta T\right)$, adsorption potential $\left(A_{\max }\right)$ of $n$-octane $K_{b} / K_{a}$ ratio, specific Gibbs free energy of adsorption $\left(\Delta G_{a d s}^{s p}\right), \Delta G_{a d s}^{s p}(\mathrm{EtOH}) /$ $\Delta G_{a d s}^{s p}(\mathrm{THF})$ ratio,and surface area $\left(S_{B E T}\right)$ were the variables introduced for the agglomerative method.

Statistical analysis was performed using IBM SPSS statistics software (V.25). The differences between parameters were assessed by a one-way analysis of variance (ANOVA), with statistical significance level of $p<0.05$.

\section{Results and discussion}

\subsection{Biosynthesis yield}

The effect of different carbon sources on the yield of BC biosynthesis was evaluated and is shown in Table 1 . The results show that the culture medium containing date syrup, as a carbon source, have the highest BC yield, $51 \%$ higher than the medium with the glucose source. Lotfiman et al. (2016) show an improvement of $68 \%$ in the BC yield with the Acetobacter xylinum 0416 bacteria, when $3 \%(\mathrm{w} / \mathrm{v})$ date syrup was applied as a carbon source after 8 days of biosynthesis. Nevertheless, Wang et al. (2018) reported that the addition of sucrose led to a decrease in the BC yield (83\%), while mannitol increased the yield by $7.6 \%$ compared with glucose after 14 days of biosynthesis with Komagataeibacter sp. W1. Thus, and based on these facts, different bacteria genera could metabolize each compound present in the culture medium in a different way, resulting in different yields of BC production.

The present study shows that low-quality/purity sources such as date syrup, sucrose, or mannitol from agricultural, industrial, forestry byproducts or waste materials can be used as an inexpensive nonconventional alternative source of carbon in the $\mathrm{BC}$ fermentation process.

\subsection{Biosynthesis process and BC morphology}

The BC obtained using the conventional carbon source - glucose shows a $B E T$ specific surface area $\left(S_{B E T}\right)$ of $34.95 \mathrm{~m}^{2} / \mathrm{g}$. The literature reports different values of $S_{B E T}$, obtained by IGC, for different bacteria species used: BC produced by Gluconacetobacter medellensis exhibited a $S_{B E T}$ of $1.94 \mathrm{~m}^{2} / \mathrm{g}$ (Castro et al., 2015), BC produced by Gluconacetobacter sp. showed a $S_{B E T}$ of $4.59 \mathrm{~m}^{2} / \mathrm{g}$ (Alonso et al., 2018) and BC produced by Gluconacetobacter sacchari presented a $S_{B E T}$ of $3.94 \mathrm{~m}^{2} / \mathrm{g}$ (Faria et al., 2019). The biological extrusion process of interconnected fibers is specific of each species of bacteria and occurs with the glucan chains extrusion from pores into the growth medium, forming microfibrils (Fig. 1). The distinct behavior of the cellulose-producing bacteria can be due to the slight dissimilarity in the enzyme's cellulose synthase. Each bacteria specie has different catalytic active sites with different domains for the enzyme's cellulose synthase (Tabaii and Emtiazi, 2016). Thus, the difference found in the $S_{B E T}$ can be due to the different cellulose-producing bacterium and/or the production conditions used, such as temperature, $\mathrm{pH}$, stirring or $\mathrm{O}_{2}$ content.

The cellulose-producing bacteria did not use all sugars to biosynthesize BC. Only the non-reducing sugars, such as glucose and fructose, are metabolized by bacteria through the pentose phosphate pathway. While glucose is easily transported through the membrane and incorporated into the biosynthetic pathway of cellulose, sucrose (reducing sugar) needs to be hydrolyzed in glucose and fructose (nonreducing sugar) (Fig. 1). Cellulose interfibrillar interaction can break down to form a smaller reticulated network structure when exposed to an acidic pH (Börjesson and Westman, 2015). Glucose oxidation occurs in the bacteria culture medium over the culture time, decreasing the $\mathrm{pH}$ of the medium. The relationship of these two factors may explain the higher surface area (smaller particle size) obtained when glucose was used.

The $S_{B E T}$ can be correlated with the particle size but also with the porosity and roughness. An increase in the porosity and/or roughness can contribute to the increase in $S_{B E T}$. However, an inverse relationship could be associated between pore size and $S_{B E T}$ (Du Plessis, 2007). According to IGC analysis, all samples present an isotherm of type I, which is characteristic of microporous materials (Fig. S1). FE-SEM was used to study the effect of the carbon sources on the BC morphology. Fig. 2(a) shows the agglomeration of the microfibers produced using glucose and Fig. 2(b) to (e) show cellulosic fibrils with higher width dispersed throughout the membrane when alternative carbon sources were used. Thus, through the FE-SEM micrographs of the BC surface, it was possible to observe that the $\mathrm{BC}$ obtained from the date syrup exhibited a more porous structure with a lower $S_{B E T}$. These BC

Table 1

Productivity and crystallinity of BC biosynthesized in Hestrin-Schramm medium with different carbon sources.

\begin{tabular}{|c|c|c|c|c|c|}
\hline \multirow[t]{2}{*}{ BC } & \multicolumn{5}{|l|}{ Carbon source } \\
\hline & Glucose & Date syrup & Mannitol & Sucrose & Food-grade sucrose \\
\hline Dry weight (g/L) & $0.88 \pm 0.15^{\mathrm{a}}$ & $1.19 \pm 0.13^{\mathrm{b}}$ & $1.34 \pm 0.10^{c}$ & $1.46 \pm 0.17^{\mathrm{b}}$ & $0.69 \pm 0.19^{d}$ \\
\hline Yield (\%) & $4.40 \pm 0.56^{\mathrm{a}}$ & $5.97 \pm 0.60^{\mathrm{b}}$ & $5.67 \pm 0.50^{\mathrm{b}}$ & $6.63 \pm 0.55^{\mathrm{b}}$ & $3.47 \pm 0.57^{\mathrm{a}}$ \\
\hline Crystallinity (\%) & $76.2 \pm 0.40$ & $75.0 \pm 0.35$ & $65.5 \pm 0.20$ & $63.2 \pm 0.15$ & $82.3 \pm 0.5$ \\
\hline $\mathbf{I}_{\boldsymbol{\beta}} / \mathbf{I}_{\boldsymbol{\alpha}}$ ratio & 0.12 & 1.20 & 0.94 & 0.70 & 0.86 \\
\hline
\end{tabular}

Values (means \pm SD) in the same row not sharing a common superscript are significantly different $(p<0.05)$. 


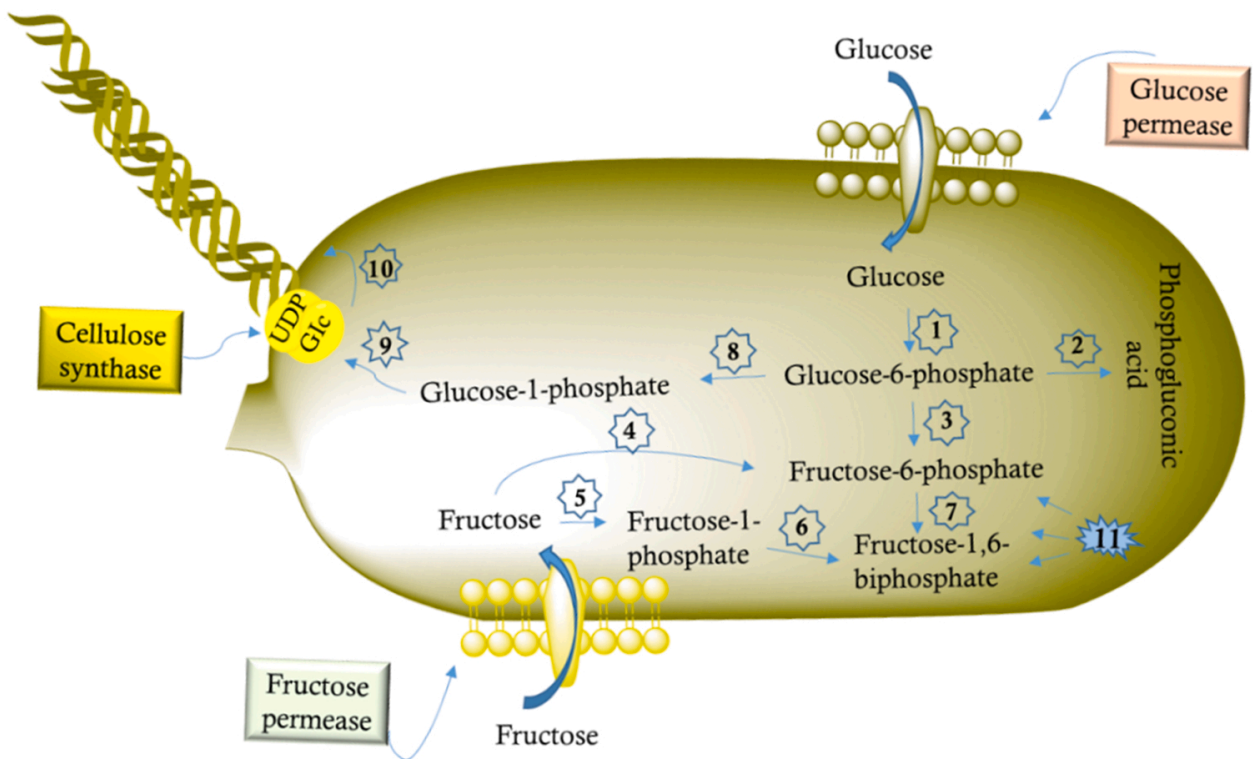

Fig. 1. Biochemical pathway for bacterial cellulose biosynthesis by Gluconacetobacter xylinum: 1- Glucokinase; 2- Glucose-6-phosphate dehydrogenase; 3- Phosphoglucoisomerase; 4- Fructokinase; 5- System of phosphotransferases; 6- Fructose-1-phosphate kinase; 7- Fructose-1,6-biphosphate; 8- Phosphoglucomutase; 9Pyrophosphorylase; 10- Cellulose synthase; 11- Metabolic pathways: Pentose phosphate cycle; Krebs cycle; Gluconeogenesis.
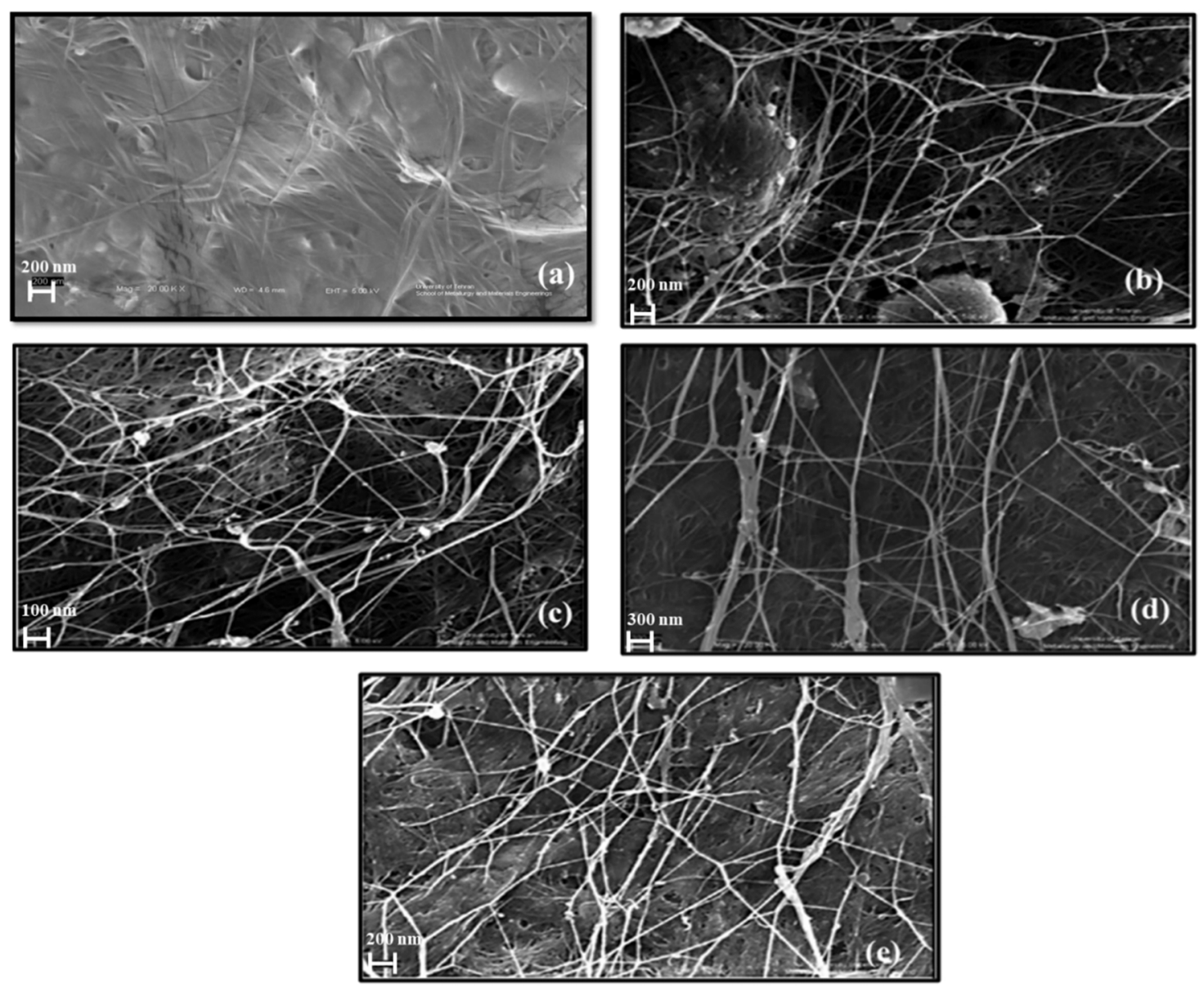

Fig. 2. FE-SEM micrographs of BC produced using different carbon sources: (a) glucose, (b) date syrup; (c) mannitol, (d) sucrose and (e) food-grade sucrose (all views with 20,000 X magnification). 
morphology findings make this $\mathrm{BC}$ a biomaterial that can be applied for biomedical applications such as tissue engineering, drug release and/or delivery, skin repair material, blood vessels, and bioremediation applications such as the removal of metals/debris from aqueous solutions (Blanco Parte et al., 2020).

Although the carbon source remained the same, the BC obtained from pure sucrose showed a more reticulated network (Fig. 2(d)), while food-grade sucrose (Fig. 2(e)) made the structure more fibrillar. This may be due to the different carbon content (food-grade sucrose - industrial food product), as the efficiency of sucrose hydrolysis to glucose and fructose is lower near the membrane. Interfibrillar hydrogen bonds were expected to break with the increase in gluconic acid due to glucose oxidation, which reduces the $\mathrm{pH}$ value. This probably led to a smaller network reticulated by intermolecular forces or/and interfibrillar bonds, which justifies the higher degree of crystallinity (82.3\%) obtained for BC produced from food sucrose (Table 1 ).

To understand the influence of gluconic acid on the BC terminal chain, the elemental composition was identified by EDX. The $O / C$ ratio (Table 2) decreased by $34 \%$ when the sucrose was used as the carbon source, while with the food-grade sucrose source it increased by $48 \%$, which corroborates what was reported above.

ATR-FTIR is usually used to identify modifications in the structure of the surface of a material throughout a specific process or treatment. In this work, the obtained ATR-FTIR spectra (Fig. S2) did not show evidence of any chemical modifications in the structure of the BC. The BC characteristic peaks are visible in all spectra at $3338,2896,1448,1148$, 1108 and $1060-1028 \mathrm{~cm}^{-1}$ corresponding to the free stretching vibration of the $(\mathrm{O}-\mathrm{H})$ group, stretching vibration $(\mathrm{C}-\mathrm{H})$, in plan bending $(\mathrm{O}-\mathrm{H})$, stretching $(\mathrm{C}-\mathrm{O}-\mathrm{C})$, deformation $(\mathrm{C}-\mathrm{H})$, stretching $(\mathrm{C}-\mathrm{C})$ ring of cellulose and stretching $(\mathrm{C}-\mathrm{O})$, respectively.

Thus, the BC biosynthesis process, and thereby also the BC morphology, was strongly affected by the carbon source used. In general, the alternative carbon sources gave rise to a $\mathrm{BC}$ polymer with longer fibrils and a greater degree of cross-linking (except to food-grade sucrose, which presents less reticulation). The BC membranes obtained using alternative carbon sources are less compact (reticulated), more porous, and more permeable to gas than the $\mathrm{BC}$ obtained using glucose as the carbon source, making the $\mathrm{BC}$ an enhanced, versatile, and desirable biomaterial with attractive properties for use in pharmaceutical applications and as a filter for bioremediation applications.

\subsection{BC surface properties}

The dispersive surface energy of BC membranes $\left(\gamma_{s}^{d}\right)$ were determined using $n$-alkane probes. The IGC analysis of BC using glucose as the carbon source displays a $\gamma_{s}^{d}$ of $37.08 \mathrm{~mJ} / \mathrm{m}^{2}$ at $25^{\circ} \mathrm{C}$ (Table 3), which is similar to that produced by Gluconacetobacter medellensis, $39.64 \mathrm{~mJ} / \mathrm{m}^{2}$ at $25^{\circ} \mathrm{C}$ (Castro et al., 2015), and by Gluconacetobacter sp., $37.65 \mathrm{~mJ} / \mathrm{m}^{2}$ at $25{ }^{\circ} \mathrm{C}$ (Alonso et al., 2018). An overview of the literature on the surface energy and acid and base surface character of $\mathrm{BC}$, is presented in Table 4.

Carbon source variation only significantly affects the $\gamma_{s}^{d}$ for the date syrup-membranes, which increased to $45.79 \mathrm{~mJ} / \mathrm{m}^{2}$ at $25^{\circ} \mathrm{C}$. This difference was due to the different synthesis conditions (sugar sources) that influenced the cellulose chain arrangement and consequently the

Table 2

EDX surface elemental analysis of BC samples (wt $\%$ ).

\begin{tabular}{llll}
\hline Carbon source & \multicolumn{3}{l}{ Surface elemental composition (wt\%) } \\
\cline { 2 - 4 } & $\mathrm{C}$ & $\mathrm{O}$ & $\mathrm{O} / \mathrm{C}$ \\
\hline Glucose & 59.88 & 37.06 & 0.62 \\
Date syrup & 74.43 & 20.65 & 0.28 \\
Mannitol & 64.62 & 26.18 & 0.41 \\
Sucrose & 66.01 & 26.94 & 0.41 \\
Food-grade sucrose & 50.30 & 46.37 & 0.92 \\
\hline
\end{tabular}

cellulose type produced. Cellulose type I is the common form produced by the bacteria and exhibits two allomorph forms: monoclinic $I_{\alpha}$ and triclinic $I_{\beta}$, distinguishable by their spatial arrangement of nanofibrils, where the $I_{\beta}$ is the most energetic form (Vitta and Thiruvengadam, 2012; Mohite and Patil, 2014; Moon et al., 2011; Iguchi et al., 2000). Modifications in stirring, temperature or additives can cause variations in the $I_{\alpha} / I_{\beta}$ ratio and in the microfibril width of BC (Forestia et al., 2017). In the present work, the high energy obtained suggests that the $I_{\beta}$ allomorph predominates over the $I_{\alpha}$ allomorph, particularly when the date syrup was used (higher $\gamma_{s}^{d}$ ). Yamamoto and Horn (1994) and Tokoh et al. (1998) show that the addition of xyloglucan and carboxymethyl cellulose sodium salt to the medium significantly increased the amount of cellulose $I_{\beta}$, which led to variations in cellulose nanostructure and crystallite size. Thus, the increase in crystallinity owing to the new orientation of cellulose chains allowed an increase in the $I_{\beta}$. Due to the different arrangements of the pyranose rings and the possible conformational changes of the hydroxymethyl groups, the cellulose chains can exhibit different crystal packings. Consequently, variations are expected in the crystallinity and in the $I_{\beta} / I_{\alpha}$ ratio of the BC membrane. All the alternative carbon sources enhanced the crystallization of $I_{\beta}$, while the $\mathrm{BC}$ obtained through the conventional medium was predominantly composed of cellulose $I_{\alpha}$, showing higher crystallinity (Table 1 ). The addition of date syrup and food-grade sucrose into culture medium enhanced the crystallization of $I_{\beta}$ with a $I_{\beta} / I_{\alpha}$ ratio of 1.20 and 0.78 , respectively. The triclinic one-chain unit cell and monoclinic two-chain unit cell conformation of cellulose type I changed the surface properties of $\mathrm{BC}$ due to the extruded disordering of microfibrils, their size and their overlapping cellulose ribbons (Krystynowicz et al., 2002).

An interesting correlation, identified for the first time, was found between the $\gamma_{s}^{d}$ and the $I_{\beta} / I_{\alpha}$ ratio (Fig. 3): an increase in the $I_{\beta} / I_{\alpha} \quad$ ratio was accompanied by an increase in the $\gamma_{s}^{d}$ value.

The surface area of $\mathrm{BC}$ largely decreased with the use of alternative carbon sources compared with the conventional source, with a $S_{B E T}$ ranging between 4.04 and $10.06 \mathrm{~m}^{2} / \mathrm{g}$ (Table 3). This decrease can be attributed to the increase in the particle size. Interference in the extrusion of interconnected fibers can provoke the aggregation of the fibers and consequently increase their particle size.

In the dispersive energetic profile of the surface heterogeneity, determined by IGC (Fig. 4), the date syrup source displays an improvement in the energetic surface through the free active sites with the highest energetic potential $\left(A_{\max }=6.57 \mathrm{~kJ} / \mathrm{Mol}\right)$, while the foodgrade sucrose source had the lowest energy of the free active sites $\left(A_{\max }=3.79 \mathrm{~kJ} / \mathrm{Mol}\right)$. These results reveal that the increase in the $\gamma_{s}^{d}$ values is due to the presence of more energetic free active sites on the $\mathrm{BC}$ surface and show that the $\mathrm{BC}$ chain configuration depends on the carbon source.

As IGC analysis evaluates the materials at molecular level, the dependence of $\gamma_{s}^{d}$ on temperature (Fig. S3) was also determined $\left(\Delta \gamma_{s}^{d} / \Delta T\right)$, to infer about the entropic contribution to the surface free energy. The different values of $\Delta \gamma_{s}^{d} / \Delta T$ obtained (Table 3) indicate that different carbon sources influenced the chain structural organization on the $\mathrm{BC}$ surface, and consequently their degrees of freedom. Thus, the food-grade sucrose source generates a 3D network structure in which the cellulose chains are strongly linked (OH bonding), which decreased the chain freedom. Using the date syrup source, an increase in the degrees of freedom of the cellulose chain was observed, making the material surface more susceptible to temperature changes, due to a lower chaincrosslink. The heterogeneity profile and the $O / C$ ratio $(0.28)$ determined by EDX analysis support this conclusion.

Using polar probes, the IGC allows determination of the specific Gibbs free energy of adsorption $\left(\Delta G_{a d s}^{s p}\right)$ as well as a prediction of how the polar groups are dispersed at the surface. BC membrane made from date syrup source shows greater interaction with the polar probes (Fig. 5), which means a more significant presence of free polar groups on the BC 
Table 3

IGC results of the obtained BC using different carbon sources, at $25^{\circ} \mathrm{C}$.

\begin{tabular}{|c|c|c|c|c|c|}
\hline \multirow[t]{2}{*}{$\mathrm{BC}$ properties } & \multicolumn{5}{|l|}{ Carbon source } \\
\hline & Glucose & Date syrup & Mannitol & Sucrose & Food-grade sucrose \\
\hline$S_{B E T}\left(\mathrm{~m}^{2} / \mathrm{g}\right)$ & $34.95 \pm 1.05^{\mathrm{a}}$ & $4.04 \pm 0.12^{\mathrm{b}}$ & $10.06 \pm 0.30^{\mathrm{c}}$ & $8.36 \pm 0.25^{c, d}$ & $9.28 \pm 0.28^{\mathrm{b}, \mathrm{d}}$ \\
\hline$n_{m}(\mathrm{mMol} / \mathrm{g})$ & $92.10 \pm 2.76^{\mathbf{a}}$ & $10.65 \pm 0.32^{b}$ & $26.52 \pm 0.80^{c}$ & $22.04 \pm 0.66^{\mathrm{c}}$ & $24.46 \pm 0.73^{\mathrm{c}}$ \\
\hline$\gamma_{s}^{d}\left(\mathrm{~mJ} / \mathrm{m}^{2}\right)$ & $37.08 \pm 1.11^{\mathrm{a}}$ & $45.79 \pm 1.37^{\mathbf{b}}$ & $39.07 \pm 1.18^{\mathrm{a}}$ & $39.40 \pm 1.17^{\mathrm{a}}$ & $38.94 \pm 1.17^{\mathrm{a}}$ \\
\hline$d \gamma_{s}^{d} / d T \quad\left(\mathrm{~mJ} / \mathrm{m}^{2} \mathrm{~K}\right)$ & -0.13 & -0.70 & -0.18 & -0.34 & -0.04 \\
\hline$\Delta G_{a d s}^{s p}(\mathrm{EtOH} / \mathrm{THF})$ & 0.70 & 0.85 & 0.78 & 0.75 & 0.67 \\
\hline$K_{a}$ & 0.10 & 0.10 & 0.10 & 0.10 & 0.09 \\
\hline$K_{b}$ & 0.07 & 0.11 & 0.08 & 0.10 & 0.07 \\
\hline$K_{b} / K_{a}$ & 0.70 & 1.10 & 0.80 & 1.00 & 0.78 \\
\hline
\end{tabular}

$S_{B E T}$ : surface area; $n_{m}$ : monolayer capacity; $\gamma_{s}^{d}$ : dispersive component of surface free energy and its variation with temperature - $d \gamma_{s}^{d} / d T$ (Fig. S3); $K_{a}$ acid and $K_{b}$ basic surface character; $\Delta G_{a d s}^{s p}$ : specific Gibbs free energy of adsorption. Values (means \pm SD) in the same row not sharing a common superscript are significantly different $(p<0.05)$.

Table 4

An overview of the surface energy, acid and base surface character of bacterial cellulose from different strains and carbon sources.

\begin{tabular}{|c|c|c|c|c|c|c|c|}
\hline Methodology & $\begin{array}{l}\gamma_{s}^{d}(\mathrm{~mJ} / \\
\left.\mathrm{m}^{2}\right)\end{array}$ & $K_{a}$ & $K_{b}$ & Strain & Medium & $\begin{array}{l}\text { Sugar } \\
\text { source }\end{array}$ & Reference \\
\hline \multirow[t]{7}{*}{ IGC } & $\begin{array}{l}39.64 \\
\left(20^{\circ} \mathrm{C}\right)\end{array}$ & 0.09 & 0.05 & Gluconacetobacter sp. & $\begin{array}{l}\text { Hestrin - } \\
\text { Schramm }\end{array}$ & Glucose & Castro et al. (2015) \\
\hline & $\begin{array}{l}52.19 \\
\left(25^{\circ} \mathrm{C}\right)\end{array}$ & 0.10 & 0.23 & Gluconacetobacter sacchari & $\begin{array}{l}\text { Hestrin - } \\
\text { Schramm }\end{array}$ & Glucose & Faria et al. (2019) \\
\hline & $\begin{array}{l}39.21 \\
\left(25^{\circ} \mathrm{C}\right)\end{array}$ & 0.06 & 0.11 & Gluconacetobacter xylinus & $\begin{array}{l}\text { Hestrin - } \\
\text { Schramm }\end{array}$ & Glucose & $\begin{array}{l}\text { Mohammadkazemi et al. } \\
\text { (2017) }\end{array}$ \\
\hline & $\begin{array}{l}37.08 \\
\left(25^{\circ} \mathrm{C}\right)\end{array}$ & 0.09 & 0.06 & Gluconacetobacter xylinus PTCC 1734 & $\begin{array}{l}\text { Hestrin - } \\
\text { Schramm }\end{array}$ & Glucose & $\begin{array}{l}\text { Mohammadkazemi et al. } \\
\text { (2016) }\end{array}$ \\
\hline & $\begin{array}{l}42.55 \\
\left(25^{\circ} \mathrm{C}\right)\end{array}$ & 0.09 & 0.09 & Gluconacetobacter xylinus PTCC 1734 & Zhou & Glucose & $\begin{array}{l}\text { Mohammadkazemi et al. } \\
\text { (2016) }\end{array}$ \\
\hline & $\begin{array}{l}37.65 \\
\left(25^{\circ} \mathrm{C}\right)\end{array}$ & - & - & Gluconacetobacter sp. & $\begin{array}{l}\text { Hestrin - } \\
\text { Schramm }\end{array}$ & Glucose & Alonso et al. (2018) \\
\hline & $\begin{array}{l}61.0 \\
\left(30^{\circ} \mathrm{C}\right)\end{array}$ & 0.11 & 0.41 & $\begin{array}{l}\text { Gluconacetobacter xylinus strain BPR } 2001 \text { (ATCC }(\text { ) } \\
\text { 700178) }\end{array}$ & Corn steep liquor & Fructose & Heng et al. (2007) \\
\hline \multirow[t]{2}{*}{ Contact angle } & $\begin{array}{l}61.53 \\
\left(20^{\circ} \mathrm{C}\right)\end{array}$ & - & - & Gluconacetobacter xylinus & $\begin{array}{l}\text { Hestrin - } \\
\text { Schramm }\end{array}$ & Glucose & Li et al. (2010) \\
\hline & $\begin{array}{l}48.28 \\
\left(20^{\circ} \mathrm{C}\right)\end{array}$ & - & - & Gluconacetobacter xylinus & $\begin{array}{l}\text { Hestrin - } \\
\text { Schramm }\end{array}$ & Glucose & Tomé et al. (2010) \\
\hline
\end{tabular}

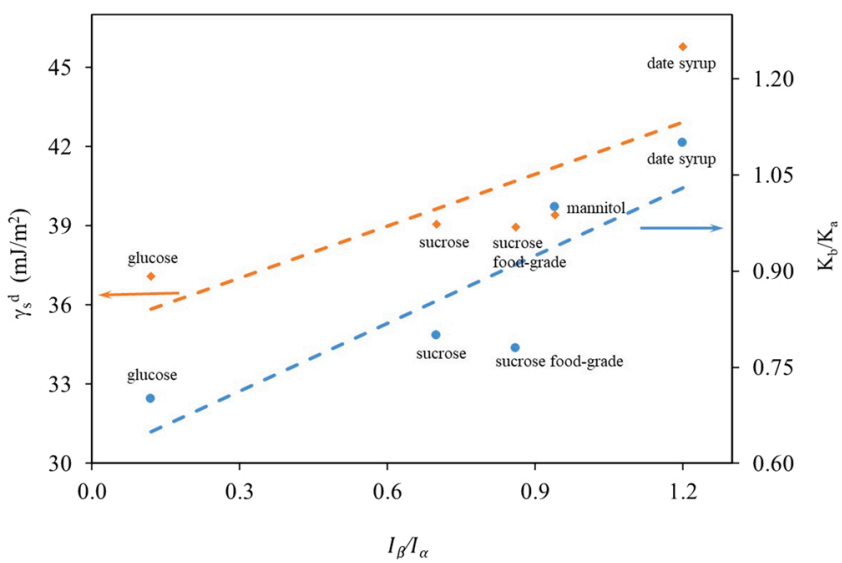

Fig. 3. Relationship between $I_{\beta} / I_{\alpha}$ ratio and: $i$ ) $\gamma_{s}^{d}$ (orange line and rhombus symbol); ii) $K_{b} / K_{a}$ (blue line and circle symbol) ratio, to BC produced using different carbon sources.

surface, according to the high value of $\Delta \gamma_{s}^{d} / \Delta T$. Compared to the glucose source, the increase was higher in the date syrup source for ethanol (acid probe: $36 \%$ ) than for tetrahydrofuran (basic probe: $11 \%$ ). This indicates that the BC produced from date syrup exhibits a predominant basic surface character. This observation was supported by the

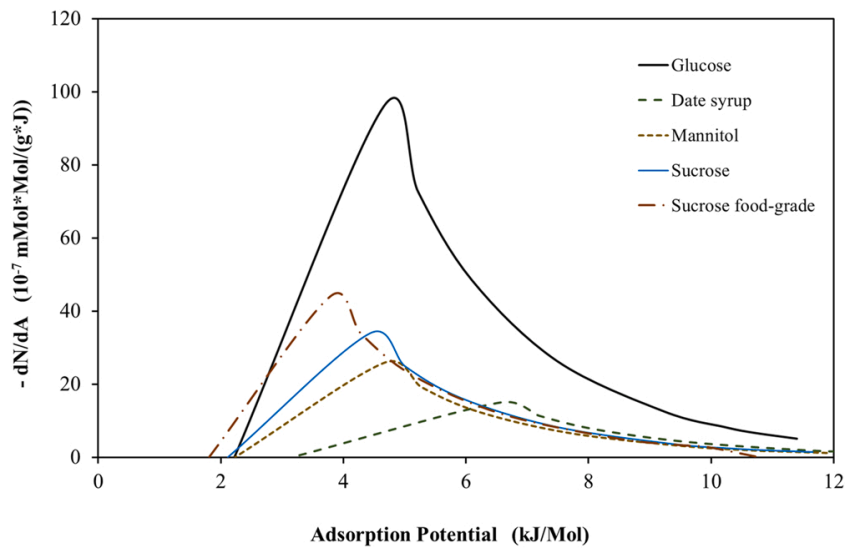

Fig. 4. n-octane heterogeneity profile for $\mathrm{BC}$ produced using different carbon sources, at $25{ }^{\circ} \mathrm{C}$.

$\Delta G_{a d s}^{s p} \quad(\mathrm{EtOH} / \mathrm{THF})$ ratio of 0.85 for the BC obtained from date syrup (Table 3). This can be due to the orientation of the $I_{\alpha}$ or $I_{\beta}$ structure of each cellulosic chain, namely the $-\mathrm{C}-\mathrm{O}-\mathrm{C}$ - group of the pyranose rings on the surface, or due to the presence of the end-reducing cellulose chain that contains two types of termination - a free hemiacetal or aldehyde, at the C5 position (Börjesson and Westman, 2015).

The membranes from alternative sources displayed an increase in 


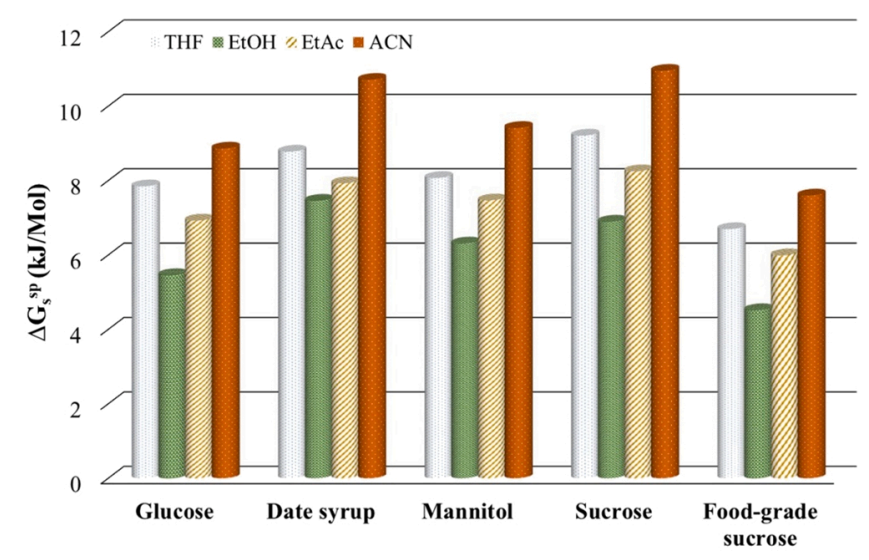

Fig. 5. Specific Gibbs free energy of adsorption $\left(\Delta G_{a d s}^{s p}\right)$ to ethanol (EtOH), tetrahydrofuran (THF), ethyl acetate (EtAc) and acetonitrile (ACN) probes, for $\mathrm{BC}$ produced using different carbon sources.

$\Delta G_{a d s}^{s p}(\mathrm{ETOH})$ suggesting that the reducing end of the cellulose form preferentially aldehyde group. From an energetic profile of ethanol and tetrahydrofuran probes, it is observed that the date syrup membrane (Fig. S4) presents the highest energetic value for the basic free active sites $\left(A_{\max }=3.29 \mathrm{~kJ} / \mathrm{Mol}\right)$ and for the acid free active sites $\left(A_{\max }=\right.$ $5.31 \mathrm{~kJ} / \mathrm{Mol}$ ). These results reflect the rearrangement and/or modification of cellulose end-chains in the $\mathrm{BC}$ structure, due to the carbon source.

The acid and base surface character $\left(K_{a}\right.$ and $\left.K_{b}\right)$ were obtained directly from the $\Delta G_{a d s}^{s p}$ values, using Guttman's concept (Guttman, 1978). The $K_{b} / K_{a}$ ratio increased in all samples compared with the conventional source, highlighting that the date syrup source holds a higher ratio (Table 3 ). This data strengthens the values obtained for all studied parameters, which suggests that a changed rearrangement of the cellulose chains leads to a surface with more ether and aldehyde groups available for polar interactions.

\subsection{Cluster analysis}

The hierarchical agglomerative clustering algorithm starts with single variables and gradually merges them into extensive groups according to the similarity of their features. The nine variables determined by IGC measurements for each culture medium with different carbon sources were subjected to this algorithm. The obtained dendogram, shown in Fig. 6, gives an outstanding representation of the similarity of IGC data, as well as the assessment of the relative magnitude of variables. In multivariate statistical analysis, the hierarchically agglomerative clustering applied reveals specific patterns of similarity among the different carbon sources. Two clusters were determined: Cluster 1 glucose, food-grade sucrose, mannitol and sucrose carbon source with $60.2 \%$ of similarity between them; and Cluster 2 - date syrup carbon source with only $17.4 \%$ of similarity among others carbon sources (Fig. 6(a)). Among all the IGC variables, it is important to understand which is responsible for the cluster formation. Through the clustering of variables (Fig. 6(b)) it is possible to observe that the variables' $A_{\max }$ of $n$ octane, tetrahydrofuran and ethanol, $K_{b} / K_{a}$ ratio, $\Delta G_{a d s}^{s p}(\mathrm{EtOH}) /$ $\Delta G_{a d s}^{s p}(\mathrm{THF})$ and $\gamma_{s}^{d}$, surface energy, contribute to the agglomeration of cluster 1 , and the variables' $S_{B E T}$, surface area, and $\Delta \gamma_{s}^{d} / \Delta T$ contribute to the agglomeration of cluster 2 . These statistical results support the IGC data, where the $\mathrm{BC}$ obtained from date syrup carbon sources stand out from the others' carbon sources.

\section{Conclusion}

A simple and low-cost approach to modify BC morphology and the
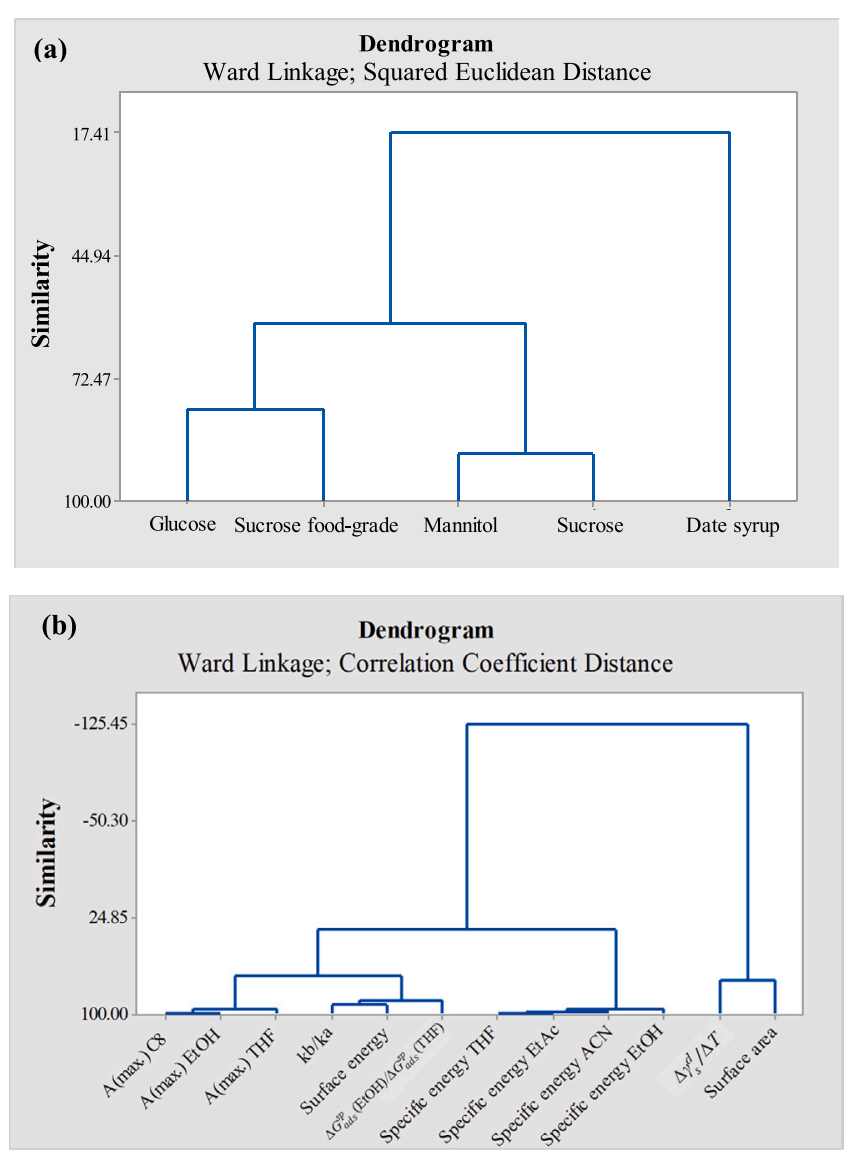

Fig. 6. Hierarchical dendrograms for clustering to each carbon sources (a) and IGC variables/parameters (b).

surface properties of $\mathrm{BC}$ during its biosynthesis by using alternative carbon sources in the culture medium has been successfully achieved. The carbon source present in the medium can lead to an extrusion of microfibrils with different sizes, widths, and crosslinks, changing the conformational orientation of the hydroxymethyl groups and the endchain groups. The rearrangements of the pyranose rings, as well as the end-reducing groups, lead to new surface properties. Thus, the carbon source chosen for BC biosynthesis affects not only the production, but also its morphology and surface properties. Surface properties such as surface area, surface energy, surface porosity, surface roughness, acid and base surface character changed significantly with the carbon source. The hierarchically agglomerative clustering allowed the visualization of the similarity of the IGC parameters, highlighting the date syrup source significatively modifies the surface properties of BC. Date syrup sources, rich in micro and macro-nutrients, make the microporous membrane of BC more hydrophobic with a more basic character. Food-grade sucrose sources induce a more reticulated $\mathrm{BC}$, which is more crystalline and has smaller $K_{b} / K_{a}$ and $\Delta \gamma_{s}^{d} / \Delta T$ ratios. Thus, this study allows evaluation of carbon sources that can be used as a modulator of the surface properties of $\mathrm{BC}$ needed for biomedical applications.

\section{CRediT authorship contribution statement}

Marisa Faria: Methodology, Validation, Formal analysis, Investigation, Data curation, Writing - original draft, Writing - review \& editing, Visualization. Fatemeh Mohammadkazemi: Conceptualization, Methodology, Formal analysis, Investigation, Data curation, Writing review \& editing, Visualization. Roberto Aguiar: Formal analysis, Investigation, Data curation. Nereida Cordeiro: Conceptualization, Methodology, Validation, Resources, Data curation, Writing - original 
draft, Writing - review \& editing, Visualization, Supervision, Project administration, Funding acquisition.

\section{Declaration of Competing Interest}

The authors declare that they have no known competing financial interests or personal relationships that could have appeared to influence the work reported in this paper.

\section{Acknowledgement}

The Portuguese authors would like to thank the National Program for Scientific Equipment Renewal, POCI 2010, for sponsoring IGC work (FEDER and Foundation for Science and Technology, Portugal).

\section{Appendix A. Supporting information}

Supplementary data associated with this article can be found in the online version at doi:10.1016/j.indcrop.2021.114447.

\section{References}

Al-Hooti, S.N., Sidhu, J.S., Al-Saqer, J.M., Al-Othman, A., 2002. Chemical composition and quality of date syrup as affected by pectinase/cellulase enzyme treatment. Food Chem. 79, 215-220. https://doi.org/10.1016/S0308-8146(02)00134-6.

Alonso, E., Faria, M., Ferreira, A., Cordeiro, N., 2018. Influence of the matrix and polymerization methods on the synthesis of BC/PANi nanocomposites: an IGC study. Cellulose 25, 2343-2354. https://doi.org/10.1007/s10570-018-1736-0.

Ashraf, Z., Hamidi-Esfahani, Z., 2011. Date and date processing: a review. Food Rev. Int. 2, 101-133. https://doi.org/10.1080/87559129.2010.535231.

Belitz, H.D., Grosch, W., 1999. Sugars, sugar alcohols and honey. Food Chemistry. Springer, Berlin, Heidelberg. https://doi.org/10.1007/978-3-662-07281-3_20.

Blanco Parte, F.G., Santoso, S.P., Chou, C.C., Verma, V., Wang, H.T., Ismadji, S., Cheng, K.C., 2020. Current progress on the production, modification, and applications of bacterial cellulose. Crit. Rev. Biotechnol. 40, 397-414. https://doi. org/10.1080/07388551.2020.1713721.

Bodin, A., Bharadwaj, S., Shaofeng, W., Gatenholm, P., Atala, A., Zhang, Y., 2010. Tissueengineered conduit using urine-derived stem cells seeded bacterial cellulose polyme in urinary reconstruction and diversion. Biomaterials 31, 8889-8901. https://doi. org/10.1016/j.biomaterials.2010.07.108.

Börjesson, M., Westman, G., 2015. Chapter 7 - Crystalline nanocellulose - preparation, modification, and properties. Cellulose - Fundamental Aspects and Current Trends. InTech, pp. 162-163. https://doi.org/10.5772/61899.

Brackmann, C., Zaborowska, M., Sundberg, J., Gatenholm, P., Enejder, A., 2012. In situ imaging of collagen synthesis by osteoprogenitor cells in microporous bacterial cellulose scaffolds. Tissue Eng. Part C Methods 18, 227-234. https://doi.org/ 10.1089/ten.TEC.2011.0211.

Castro, C., Cordeiro, N., Faria, M., Zuluaga, R., Putaux, J., Filpponen, I., Velez, L., Rojas, O.J., Gañán, P., 2015. In-situ glyoxalization during biosynthesis of bacterial cellulose. Carbohydr. Polym. 126, 32-39. https://doi.org/10.1016/j. carbpol.2015.03.014.

Cava, D., Gavara, R., Lagarón, J.M., Voelkel, A., 2007. Surface characterization of poly (lactic acid) and polycaprolactone by inverse gas chromatography. J. Chromatogr. A 1148 (1), 86-91. https://doi.org/10.1016/J.CHROMA.2007.02.110.

Cordeiro, N., Gouveia, C., Moraes, A., Amico, S., 2011. Natural fibers characterization by inverse gas chromatography. Carbohydr. Polym. 84, 110-117. https://doi.org/ 10.1016/j.carbpol.2010.11.008.

Du Plessis, M., 2007. Relationship between specific surface area and pore dimension of high porosity nanoporous silicon - model and experiment. Phys. Stat. Sol. (a) 204 (7), 2319-2328. https://doi.org/10.1002/pssa.200622237.

Fang, Q., Zhou, X., Deng, W., Liu, Z., 2016. Freestanding bacterial cellulose-graphene oxide composite membranes with high mechanical strength for selective ion permeation. Sci. Rep. 6, 33185. https://doi.org/10.1038/srep33185.

Faria, M., Vilela, C., Silvestre, A.J.D., Deepa, B., Resnik, M., Freire, C.S.R., Cordeiro, N., 2019. Physicochemical surface properties of bacterial cellulose/polymethacrylate nanocomposites: an approach by inverse gas chromatography. Carbohydr. Polym. 206, 86-93. https://doi.org/10.1016/j.carbpol.2018.10.110.

Forestia, M.L., Vázqueza, A., Boury, B., 2017. Applications of bacterial cellulose as precursor of carbon and composites with metal oxide, metal sulfide and metal nanoparticles: a review of recent advances. Carbohydr. Polym. 157, 447-467. https://doi.org/10.1016/j.carbpol.2016.09.008.

Gonçalves, S., Padrão, J., Rodrigues, I.P., Silva, J.P., Sencadas, V., Lanceros-Mendez, S., et al., 2016. Bacterial cellulose as a support for the growth of retinal pigment epithelium. Biomacromolecules 16, 1341-1351. https://doi.org/10.1021/acs. biomac.5b00129.

Guttman, V., 1978. The Donor-Acceptor Approach to Molecular Interactions, first ed. Plenum Publ. Corp., New York.
Heng, J.Y.Y., Pearse, D.F., Thielmann, F., Lampke, T., Bismarck, A., 2007. Methods to determine surface energies of natural fibres: a review. Compos. Interface 14. https:// doi.org/10.1163/156855407782106492.

Hussain, Z., Sajjad, W., Khan, T., Wahid, F., 2019. Production of bacterial cellulose from industrial wastes: a review. Cellulose 26, 2895-2911. https://doi.org/10.1007/ s10570-019-02307-1.

Iguchi, M., Yamanaka, S., Budhiono, A., 2000. Bacterial cellulose - a masterpiece of nature's arts. J. Mater. Sci. 35, 261-270. https://doi.org/10.1023/A: 1004775229149.

Jozala, A.F., Celia De Lencastre-Novaes, L., Lopes, A.M., De, V., Santos-Ebinuma, C., Gava Mazzola, P., Pessoa-Jr, A., Grotto, D., Gerenutti, M., Chaud, M.V., 2016. Bacterial nanocellulose production and application: a 10-year overview. Appl. Microbiol. Biotechnol. 100, 2063-2072. https://doi.org/10.1007/s00253-015-72434.

Krishnamurthy, M., Lobo, N.P., Samanta, D., 2020. Improved hydrophobicity of a bacterial cellulose surface: click chemistry in action. ACS Biomater. Sci. Eng. 6 , 879-888. https://doi.org/10.1021/acsbiomaterials.9b01571.

Krystynowicz, A., Czaja, W., Wiktorowska-Jezierska, A., Gonçalves-Miśkiewicz, M., Bielecki, S., 2002. Factors affecting the yield and properties of bacterial cellulose. J. Ind. Microbiol. Biotechnol. 29, 189-195. https://doi.org/10.1038/sj. jim.7000303.

Li, Z.Q., Zhou, X.D., Pei, C.H., 2010. Synthesis of PLA-co-PGMA copolymer and its application in the surface modification of bacterial cellulose. Int. J. Polym. Mater 59, 725-737. https://doi.org/10.1080/00914037.2010.483214.

Lotfiman, S., Biak, D.R.A., Ti, T.B., Kamarudin, S., Nikbin, S., 2016. Influence of date syrup as a carbon source on bacterial cellulose production by Acetobacter xylinum 0416. Adv. Polym. Sci. 37, 4. https://doi.org/10.1002/adv.21759.

Mohammadkazemi, F., Faria, M., Cordeiro, N., 2016. In situ biosynthesis of bacterial nanocellulose- $\mathrm{CaCO}_{3}$ hybrid bionanocomposite: one-step process. Mater. Sci. Eng. C 65, 393-399. https://doi.org/10.1016/j.msec.2016.04.069.

Mohammadkazemi, F., Aguiar, R., Cordeiro, N., 2017. Improvement of bagasse fibercement composites by addition of bacterial nanocellulose: an inverse gas chromatography study. Cellulose 24, 1803-1814. https://doi.org/10.1007/s10570017-1210-4.

Mohite, B., Patil, S., 2014. A novel biomaterial: bacterial cellulose and its new era applications. Biotechnol. Appl. Biochem. 61, 101-110. https://doi.org/10.1002/ bab.1148.

Moon, R., Martini, A., Nairn, J., Simonsen, J., Youngblood, J., 2011. Cellulose nanomaterials review: structure, properties, and nanocomposites. Chem. Soc. Rev. 40, 3941-3984. https://doi.org/10.1039/C0CS00108B.

Moosavi-Nasab, M., Yousefi, A., 2011. Biotechnological production of cellulose by Gluconacetobacter xylinus from agricultural waste. Iran. J. Biotechnol. 9, 94-101.

Park, S., Yoon, S., Son, H., Lee, C., Kim, H., 2010. Properties of bacterial cellulose cultured in different carbon sources. Polymer 34, 522-526. https://doi.org/ 10.7317/pk.2010.34.6.522.

Pircher, N., Veigel, S., Aigner, N., Nedelec, J.N., Rosenau, T., Liebner, F., 2014. Reinforcement of bacterial cellulose aerogels with biocompatible polymers. Carbohydr. Polym. 11, 505-513. https://doi.org/10.1016/j.carbpol.2014.04.029.

Pötzinger, Y., Kralisch, D., Fischer, D., 2017. Bacterial nanocellulose: the future of controlled drug delivery? Ther. Deliv. 8, 753-761. https://doi.org/10.4155/tde2017-0059.

Rühs, P.A., Storz, F., Gómez, Y.A.L., Haug, M., Fischer, P., 2018. 3D bacterial cellulose biofilms formed by foam templating. npj Biofilms Microbiomes 4, 21. https://doi. org/10.1038/s41522-018-0064-3.

Silva, N.H.C.S., Drumond, I., Almeida, I.F., Costa, P., Rosado, C.F., Neto, C.P., Freire, C.S. R., Silvestre, A.J.D., 2014. Topical caffeine delivery using biocellulose membranes: a potential innovative system for cellulite treatment. Cellulose 21 (1), 665-674. https://doi.org/10.1007/s10570-013-0114-1.

Stumpf, T.R., Pértile, R.A.N., Rambo, C.R., Porto, L.M., 2013. Enriched glucose and dextrin mannitol-based media modulates fibroblast behavior on bacterial cellulose membranes. Mater. Sci. Eng. C 33, 4739-4745. https://doi.org/10.1016/j. msec. 2013.07.035.

Tabaii, M., Emtiazi, G., 2016. Comparison of bacterial cellulose production among different strains and fermented media. Appl. Food Biotechnol. 3, 35-41. https://doi. org/10.22037/afb.v3i1.10582.

Thielmann, F.J., 2004. Introduction into the characterisation of porous materials by inverse gas chromatography. Chromatography A 1037, 115-123. https://doi.org/ 10.1016/j.chroma.2004.03.060.

Tokoh, C., Takabe, K., Fujita, M., Saiki, H., 1998. Cellulose synthesized by Acetobacter xylinum in the presence of acetyl glucomannan. Cellulose 5, 249-261. https://doi. org/10.1023/A:1009211927183.

Tomé, L.C., Brandão, L., Mendes, A.M., Silvestre, A.J.D., Neto, C.P., Gandini, A., Freire, C.S.R., Marrucho, I.M., 2010. Preparation and characterization of bacterial cellulose membranes with tailored surface and barrier properties. Cellulose 17, 1203-1211. https://doi.org/10.1007/s10570-010-9457-z.

Tsouko, E., Kourmentz, C., Ladakis, D., Kopsahelis, N., Mandala, I., Papanikolaou, S., Paloukis, F., Alves, V., Koutinas, A., 2015. Bacterial cellulose production from industrial waste and by-product streams. Int. J. Mol. Sci. 16, 14832-14849. https:// doi.org/10.3390/ijms160714832.

Urbina, L., Hernández-Arriaga, A., Eceiza, A., Gabilondo, N., Corcuera, M., Prieto, M., Retegi, A., 2017. By-products of the cider production: an alternative source of nutrients to produce bacterial cellulose. Cellulose 24, 2071-2082. https://doi.org/ 10.1007/s10570-017-1263-4.

Vitta, S., Thiruvengadam, V., 2012. Multifunctional bacterial cellulose and nanoparticleembedded composites. Curr. Sci. 102, 1398-1405. https://doi.org/10.1007/s10570018-1755-x. 
Voelkel, A., 2006. Inverse gas chromatography: characterization of polymers, fibers, modified silicas, and surfactants. Crit. Rev. Anal. Chem. 22 (5), 411-439. https:// doi.org/10.1080/10408349108051641.

Wang, S.-S., Han, Y.-H., Chen, J.-L., Zhang, D.-C., Shi, X.-X., Ye, Y.-X., Chen, D.-L., Li, M., 2018. Insights into bacterial cellulose biosynthesis from different carbon sources and the associated biochemical transformation pathways in Komagataeibacter sp. W1. Polymers 10, 963. https://doi.org/10.3390/polym10090963.
Witkiewicz, Z., Slomkiewicz, P., 2019. Gas chromatography: inverse gas chromatography. In: Encyclopedia of Analytical Science, 193-201. https://doi.org/ 10.1016/B978-0-12-409547-2.13976-9.

Yamamoto, H., Horn, F., 1994. In situ crystallization of bacterial cellulose I. Influences of polymeric additives, stirring and temperature on the formation celluloses $I_{\alpha}$ and $I_{\beta}$ as revealed by cross polarization/magic angle spinning (CP/MAS) ${ }^{13} \mathrm{C}$ NMR spectroscopy. Cellulose 1, 57-66. https://doi.org/10.1007/BF00818798. 